University of Nebraska - Lincoln

DigitalCommons@University of Nebraska - Lincoln

Court Review: The Journal of the American

Judges Association

American Judges Association

2019

Judicial Recall and Retention in the \#MeToo Era

Jordan M. Singer

Follow this and additional works at: https://digitalcommons.unl.edu/ajacourtreview

This Article is brought to you for free and open access by the American Judges Association at DigitalCommons@University of Nebraska - Lincoln. It has been accepted for inclusion in Court Review: The Journal of the American Judges Association by an authorized administrator of DigitalCommons@University of Nebraska Lincoln. 


\section{Judicial Recall and Retention in the \#MeToo Era}

\section{Jordan $M$. Singer}

$\mathbf{T}$ he voter recall of California judge Aaron Persky in June 2018 was a watershed cultural moment. For the first time in more than forty years, a sitting judge had been removed from the bench, by the local citizenry, in a special election. The recall-instigated in reaction to Judge Persky's lenient sentence for a defendant convicted of three counts of sexual assault-was hailed as a major political victory for the \#MeToo movement, and a sign of an emerging consensus that soft treatment of sex offenders within the justice system is no longer acceptable.

Any questions about the sustainability of the moment were answered five months later, when Alaska voters removed another experienced trial judge, Michael Corey, on similar grounds. Like Judge Persky, Judge Corey drew national attention after granting a light sentence to a sexual offender. As was true with Judge Persky, the sentence stirred widespread dismay and local protest. And as they had with Judge Persky, political activists rapidly organized to remove Judge Corey from the bench, arguing that his actions constituted a dereliction of judicial duty. The campaigns in California and Alaska employed similar messaging and similar methods of outreach. And both campaigns saw the judge's removal as merely the first step of a larger political movement to change existing law and social attitudes about sexual assault.

Given their outward resemblance, it is tempting to view the ousters of Judge Persky and Judge Corey as the shared-even inevitable-product of a particular cultural and political era. But in one important respect, the two events were fundamentally different. Judge Persky faced a recall election, a process that is both rare and difficult to implement, and which is specifically designed as an outlet for voters to protest particular judicial decisions. By contrast, Judge Corey faced a retention election, an occurrence that is both automatic and routine, and which is designed to allow voters to assess the judge's overall performance without regard to specific decisions. Recall elections and retention elections have different purposes, different histories, and, typically, different outcomes. That a recall effort and a retention bid could produce such similar campaigns, with such similar results, is therefore noteworthy.

The crossover nature of the anti-Corey campaign also merits close attention. Recall campaigns are premised on popular accountability, and are intended in part to channel voter outrage over particular judicial decisions or comments. Retention elections, by contrast, embrace a vision of professional accountability, a broader view that focuses on a judge's skill, competence, and demeanor. Until 2018, the tone and tactics of recall elections had never worked in a retention setting. But the campaign against Judge Corey bucked this trend, successfully turning a retention election into a referendum on a single judicial decision. It is a worrisome development.

\section{JUDICIAL SELECTION AND THE PURSUIT OF INSTITUTIONAL LEGITIMACY}

This article examines the contrasting visions of judicial accountability in recall and retention elections, with particular application to the anti-Corey campaign. Judicial accountability is a core component of judicial legitimacy, which itself is a reflection of the public's faith in the courts' institutional competence. Judicial legitimacy flows from the belief that judges will interpret and apply the law in a generally trustworthy manner consistent with their constitutional obligations. ${ }^{1}$ Legitimacy is the lifeblood of the courts: without it, they cannot obtain public support for their rulings, ${ }^{2}$ or even the material resources they need to operate. ${ }^{3}$

The methods by which judges are selected or removed occupy a central role in establishing the courts' legitimacy. This is true because-unlike private organizations that can hire the candidates most suited to their needs and goals-courts lack the power to choose their own members. It is therefore imperative upon those who do select judges to provide the courts with jurists who are capable and willing to rule fairly, honestly, and thoughtfully. Judges must be sufficiently independent that their decisions are not unduly influenced by political or social pressure, and sufficiently accountable that their decisions are grounded in established legal principles and practices. The history of judicial selection in the United States reflects an ongoing conversation about how best to accomplish that balance.

From the earliest days of the Republic, it was understood that protecting the legitimacy of the courts meant adequately distancing judges from the patronage of individual political actors. Accordingly, eight of the thirteen original states vested judicial appointment power in the state legislature, and the remaining five required an independent council to advise on or approve the governor's judicial choices. ${ }^{4}$ Save a couple of local experiments, legislative or council-based gubernatorial appointment remained the dominant form of state judicial selection for the next seventy-five years.

In the 1840s, however, a series of financial panics triggered by overspending state governments seriously eroded citizen

\section{Footnotes}

1. See Richard H. Fallon, Legitimacy and the Constitution, 118 Harv. L. Rev. 1787, 1828 (2005)

2. See Damon M. Cann \& Jeff Yates, Homegrown Institutional Legitimacy: Assessing Citizens' Diffuse Support for State Courts, 36 Am. POL. RsCH. 297, 303 (2008).

3. See Jordan M. Singer, The Federal Courts' Rulemaking Buffer, 60 WM. \& MARY L. REV. __ (forthcoming 2019), available at https://ssrn.com/abstract=3174886.

4. See Larry C. Berkson, Judicial Selection in the United States: A Special Report, 64 JudicATURE 176, 176 \& n.1 (1980). 
trust in their legislatures. ${ }^{5}$ The episode raised questions not only about the institutional competence of state representatives, but also of the judges they appointed. Reformers argued that if judges who owed their office to legislators were not independent enough to prevent legislative malfeasance, a different method of selecting judges was needed. The agreedupon solution was direct elections, reflecting the belief that judges who were directly chosen by the people could protect against corruption or incompetence in the other branches. New York adopted direct elections in 1846, and many other states quickly followed suit. By 1861, the majority of states (twenty-four in all) had changed their constitutions to provide for selection of judges by popular vote. 6

Direct elections resolved public concerns about undue judicial fealty to legislatures, but over time elections themselves came under fire. For one thing, candidates running for judicial office had to align themselves with a political party, which seemed at odds with the impartial administration of justice. Of even greater concern, judges in many cities eventually became enmeshed in machine politics. ${ }^{7}$ Democratic party boss Tom Pendergast, for example, notoriously controlled all judicial bids in Kansas City for decades, rewarding judges who ruled in his favor and seeking a swift end to the careers of those who dared to rule against him. ${ }^{8}$

Such blatant exercises of political control inspired another modification-nonpartisan elections-which permitted judicial candidates to appear on the ballot without a party designation. This selection method removed some of the overtly political tones from contested judicial elections, but still left open the question of whether a judge so accountable to a single group of voters (or party bosses) could truly be seen as impartial. ${ }^{9}$ As the twentieth century dawned, the public commitment to the courts' institutional legitimacy endured, but the optimal method of balancing judicial accountability and judicial independence remained elusive.

\section{RETENTION ELECTIONS AND THE SHIFT TO PROFESSIONAL ACCOUNTABILITY}

In 1914, Northwestern University law professor Albert Kales proposed a new type of selection method known as merit selection. The proposal eliminated contested elections altogether and replaced them with a system that allocated the responsibility of judicial selection among a number of different actors. ${ }^{10}$ Specifically, it called for a nonpartisan nominating commission to present a slate of qualified judicial candidates to the governor, who would then appoint one of the nominees to an open seat. Each appointed judge would subsequently face periodic retention elections, in which the judge would run unopposed, the only question facing voters being whether the judge should be retained on the bench. The proposal was quickly embraced by the American Judicature Society, and later by the American Bar Association.

Merit selection was designed in part to improve public perceptions of the courts' institutional competence, by embracing professional accountability and expertise as core principles of the judicial role. This was no accident. In the early twentieth century, lawyers themselves were undergoing a professional revolution, highlighted by the emergence of graduate legal instruction and an organized bar, and the same technocratic ideals were being carried over to the judiciary. ${ }^{11}$ Merit selection accordingly utilized a similarly technocratic mechanism for choosing judges. It relied on a commission of knowledgeable experts, assuring (at least in theory) that only the most qualified and capable judges would be selected. It sought to hold newly appointed judges accountable for their efficiency and workmanship, rather than specific case outcomes. And if an unqualified or nakedly partisan judge somehow slipped through the initial selection process, retention elections guaranteed that voters could remove the offending judge on their own.

Retention elections were arguably the foremost innovation of the Kales proposal, designed to avoid the characteristics of contested judicial elections-fundraising, advertising, public policy pronouncements, interest group meetings, and currying favor with party bosses-that most clearly undermined the courts' institutional legitimacy. Running unopposed and solely on his or her own record, a judge could sidestep these political landmines. But retention elections presented another problem: most voters did not know enough about their judges to make meaningful decisions about whether they should be retained. As a consequence, some voters chose not to cast retention ballots at all, while others relied on low-quality proxy information about the judge-such as the judge's surname or perceived gender or ethnicity - to inform their decisions. ${ }^{12}$

One solution to this knowledge gap was to provide voters with information regarding each judge's professional skills and demeanor, either informally through polls of local bar associations or formally through state-run judicial performance evaluation (JPE) programs. The first JPE program began in Alaska in 1975, and similar programs had spread to nineteen states by the mid-2000s. In its most robust form, JPE evaluates individual
5. See Jed Handelsman Shugerman, The People's Courts: Pursuing JudiCIAL INDEPENDENCE IN AMERICA 84-86 (2012).

6. Id. at 276-77.

7. See Jona Goldschmidt, Merit Selection: Current Status, Procedures, and Issues, 49 U. Miami L. Rev. 1, 5-6 (1994).

8. See Laura Denvir Stith \& Jeremy Root, The Missouri Nonpartisan Court Plan: The Least Political Method of Selecting High Quality Judges, 74 Mo. L. REv. 711, 722 (2009).

9. See Matthew J. Streb, The Study of Judicial Elections, in RunNing for Judge: The Rising Political, Financial, and Legal Stakes of
Judicial Elections 10 (Matthew Streb ed., 2007).

10. See Goldschmidt, supra note 7 , at 8 .

11. See Paul D. Carrington, Judicial Independence and Democratic Accountability in Highest State Courts, 61 LaW \& Contemp. Probs. 79, 93 (1998).

12. See Jordan M. Singer, Knowing Is Half the Battle: A Proposal for Prospective Performance Evaluations in Judicial Elections, $29 \mathrm{U}$. Ark. Little Rock L. Rev. 725, 727-28 (2007) (identifying common voter proxies). 


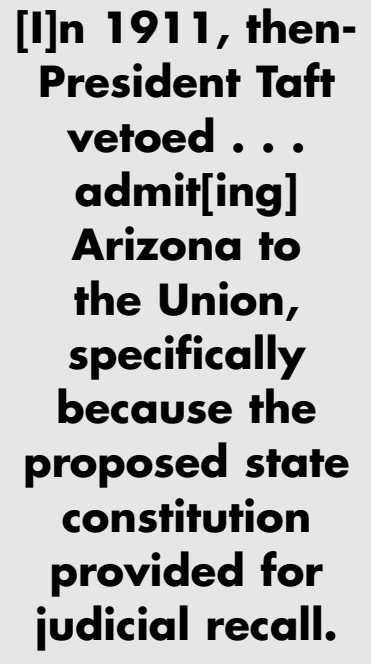

judges on five criteria directly related to the process of adjudication, using a variety of informational sources. ${ }^{13}$ The outcomes of particular cases are never considered as part of the evaluation. Independent, nonpartisan commissions then decide whether each evaluated judge meets a set of predetermined performance standards, and transmit that information to voters through voter guides, websites, and (increasingly) social media. By focusing on the qualities that make a judge a good professional, JPE programs aim to improve both judicial accountability (by presenting meaningful information to voters about a sitting judge's performance) and judicial independence (by educating voters about the content-neutral qualities they should expect in a judge). Indeed, the capacity of JPE programs to emphasize and contextualize judicial professionalism has led to their adoption not just in merit-selection states, but also in states with appointment systems and contested judicial elections.

Today, a mosaic of judicial selection methods is in use across the country, encompassing gubernatorial and legislative appointment, partisan and nonpartisan elections, and merit selection, in addition to local variants. Regardless of their preferred methods, however, states continue to emphasize the importance of their courts' institutional legitimacy, and most states have embraced judicial professionalism as a key contributor to that goal.

\section{RECALL ELECTIONS AS A FORM OF POPULAR ACCOUNTABILITY}

Retention elections came out of a longstanding national dialogue about the best way to construct a legitimate judiciary. Not so for recall elections, which from their inception were seen as a narrower housecleaning measure. The impetus for recall was a political battle between judges and social reformers during the first two decades of the twentieth century. During that period, the Supreme Court invalidated several notable pieces of economic and social legislation, drawing the wrath of populists and Progressives. Theodore Roosevelt and William Jennings Bryan, among others, characterized the judges responsible for these decisions as unaccountable actors who bent the law to suit their own economic and social philosophies, and argued that such decisions would undermine the broader legitimacy of the judiciary. These concerns nourished an ultra-reform movement at both the state and federal level, which sought to give the public much greater control over judges and their decisions.

A key plank in the ultra-reform platform was the recall election, a tool that would allow voters to remove judges who were perceived as not properly discharging their responsibilities. As one proponent explained, recall elections were a way to surgically excise unaccountable judges from an otherwise trustworthy judicial branch. ${ }^{14}$ In 1903, California became the first state to allow the popular recall of judges, and several other states quickly followed suit. ${ }^{15}$ At the state and federal level, Progressives also suggested allowing voters to recall (that is, override) specific judicial decisions. ${ }^{16}$

Because judicial recall is such a blunt and potent tool for public management of the judiciary, states adopting the procedure intentionally made it difficult to implement. In California, for example, merely placing a recall of a superior court judge on the ballot requires proponents to prepare, file, and publish a notice of intention; prepare and receive approval of the recall petition; collect valid signatures equal to at least 20 percent of the last vote for the office; and file the petition before a designated statutory deadline. ${ }^{17}$ The vast majority of recall efforts stumble over these early hurdles and die out well before Election Day. 18

Even with these procedural protections in place to prevent abuse, judicial recall was not universally supported. Indeed, prominent conservatives of the Progressive Era-among them William Howard Taft and Roscoe Pound-were horrified by the idea. They argued instead that any sort of election involving judges "enmeshed the judiciary in politics, undermined respect for the courts, and discouraged the selection of highly qualified jurists."19 Recall elections also clashed with the developing notions of judicial professionalism, which Taft held dear and which he routinely touted during and after his presidency. In a moment of high drama in 1911, then-President Taft vetoed a joint congressional resolution that would have admitted Arizona to the Union, specifically because the proposed state constitution provided for judicial recall. ${ }^{20}$ Still, recall remained in the public discourse, and many states-seeing no philosophical inconsistency between recall and retentioneventually adopted both practices.

\section{THE DIVERGENT PATHS OF RECALL AND RETENTION ELECTIONS}

Recall and retention elections differ not only in their goals, but also in the way they have been used over time. Recall elections represent a rare and particularly combustible form of
13. See Rebecca Love Kourlis \& Jordan M. Singer, A Performance Evaluation Program for the Federal Judiciary, 86 DENv. U .L. REv. 1, 10 (2008).

14. See, e.g., Senator Robert L. Owen, The Recall of Judges, 21 Yale L.J. 655, 656 (1911).

15. See G. Alan Tarr, Do Retention Elections Work?, 74 Mo. L. Rev. 605, 607 (2009).

16. See Barry Friedman, "Things Forgotten" in the Debate over Judicial Independence, 14 GA. ST. U.L. REv. 736, 747-48 (1997).

17. See California Elections Code $\S \S 11006$ et seq.
18. Before the Persky recall, there were 164 attempts to recall state officials in California. Only ten of these attempts actually made it to the ballot, and five were successful. See California Secretary of State, Recall History in California (1913 to present), available at https://www.sos.ca.gov/elections/recalls/recall-history-california1913-present.

19. Tarr, supra note 15 , at 607.

20. See W.F. Dodd, The Recall and the Political Responsibility of Judges, 10 Mich. L. REV. 79, 82-83 (1911). 
judicial accountability. Before the Persky vote last June, there had not been a successful recall of a state judge since 1977, when Wisconsin judge Archie Simonson was removed from the bench in reaction to his controversial statements about the community's "sexually permissive environment" during the sentencing of a teenage boy convicted of rape. ${ }^{21}$ In both the Persky and Simonson episodes, popular outrage over a specific incident fueled the recall movement.

None of this has been characteristic of retention elections, which occur on a set schedule in merit selection states, and which emphasize professional, as opposed to popular, accountability for judges. With the inclusion of JPE programs in many states, retention elections are increasingly framed as an exercise in citizen-initiated professional review. Voters are asked to consider the judge's demonstrated administrative ability, communication skills, legal knowledge, impartiality, and courtroom demeanor-all aspects of professionalism and all divorced from assessment of particular decisions or case outcomes. As a result, most retention elections have evolved into relatively quiet and apolitical affairs. To be sure, there have been periodic efforts to not retain judges in reaction to specific case outcomes, mostly originating from the right side of the political spectrum. But perhaps because citizens in merit-selection states have been conditioned to expect their judges to be impartial, professional, and fair, these single-issue campaigns are rarely successful. Indeed, even when judges decide controversial issues shortly before an election, voters typically choose to retain them on the basis of their overall professionalism and body of work. ${ }^{22}$

Campaigns against the retention of specific judges have found success on rare occasions, but never by making the election a referendum on a particular case outcome. Instead, these campaigns have asserted more broadly that the targeted judges lacked professionalism and institutional humility. In 1986, for example, three California supreme court justices lost their bids for retention after an extensive campaign aimed at their decisions to overturn death sentences in several criminal cases. ${ }^{23}$ Although the motivation for the campaign was a substantive disagreement over the acceptability of capital punishment, the message to the voters-at least in part-was something more fundamental: the targeted judges had overstepped their institutional role, substituted their judgment for that of the people, and compromised the legitimacy of the judiciary itself. ${ }^{24}$ In three other instances in which state supreme court justices were not retained-in Nebraska and Tennessee in 1996,25 and in Iowa in 201026 - the anti-retention campaigns employed the same strategy, framing the targeted judges' decisions not as a mere policy preference, but rather as an egregious example of professional dereliction and institutional overreach. ${ }^{27}$

The success of these particular anti-retention campaigns illustrates how deeply engrained impartiality and humility are in citizen expectations of the judge's professional role. The campaign organizers recognized that voters expected their judges to respect the legislative process, the separation of powers, and the rule of law more generally. Accordingly, these anti-retention campaigns deliberately focused on the limited role of the courts in the larger structure of American government, allowing them to further suggest that the targeted judges had made policy choices that were properly left to the legislature or to the people themselves. ${ }^{28}$

It bears emphasis that even this theme of institutional overreach rarely produces the desired results for anti-retention forces. Most judges who face retention cannot be easily caricatured as overstepping their bounds or acting outside of their responsibilities. Most professionally sound judges are retained. And the handful of judges who lack professional demeanor or competence are usually not returned on those grounds alone.

Judicial retention elections across the country in 2018 were largely consistent with these historical trends. Most judges seeking to continue their service were comfortably retained; those who were not retained typically had received poor performance evaluations. But 2018 also witnessed the emergence of a new kind of anti-retention campaign, built on the model of Persky recall, which was seen most clearly in the efforts to remove Judge Michael Corey from his seat on the Alaska Superior Court.

\section{THE UNCONVENTIONAL CAMPAIGN AGAINST JUDGE COREY}

Judge Corey was first appointed to the bench in 2014, and faced a retention election at the end of his four-year term. In August 2018, Corey received a strong performance evaluation from the Alaska Judicial Council, which unanimously recommended that voters retain him. ${ }^{29}$ But with only weeks before
21. Anita Clark, Judge to Press Simonson Case, St. J., Jun. 18, 1977.

22. See, e.g., Kourlis \& Singer, supra note 13, at 21.

23. See John T. Wold \& John H. Culver, The Defeat of the California Justices: The Campaign, the Electorate, and the Issue of Judicial Accountability, 70 Judicature 348, 349 (1987); John H. Culver \& John T. Wold, Rose Bird and the Politics of Judicial Accountability in California, 70 Judicature 81, 86 (1986) (noting that "[b]y May 1986 , the [state supreme court] had overturned death sentences in all but three of the 56 cases it had decided").

24. See Robert S. Thompson, Judicial Retention Elections and Judicial Method: A Retrospective on the California Retention Election of 1986, 61 S. CAL. L. Rev. 2007, 2038-39 (1987).

25. See Traciel V. Reid, The Politicization of Retention Elections: Lessons from the Defeat of Justices Lanphier and White, 83 JUDICATURE 68, 70 (1999).

26. See Jordan M. Singer, The Mind of the Judicial Voter, 2011 Mich. ST. L. REv. 1443, 1471-1474 (2012).

27. The framing of these allegations for political purposes, of course, does not equate to their veracity.

28. See Jordan M. Singer, Meaningful Information, Meaningful Retention, 60 BufF. L. Rev. 1, 5-6 (2012).

29. See Alaska Judicial Council, Summary of Performance Evaluation for Judge Michael D. Corey, Third District Superior Court, available at http://www.ajc.state.ak.us/sites/default/files/imported/ selection/11-2018/Judges/corey.pdf. 


\section{[T]he approach taken by No More Free \\ Passes differed significantly from the handful of previous, successful anti- retention efforts.}

the election, a seemingly quiet retention bid would become much more explosive.

In mid-September, Judge Corey was asked to approve a plea agreement in a criminal case involving stomach-churning facts. The defendant was alleged to have offered a ride to the victim, which she accepted. He drove her to a dead-end street, where he asked her to get out of the car, tackled her, and strangled her until she lost consciousness. He then ejaculated onto her body and waited until she regained consciousness before driving away. The defendant was initially charged with firstdegree kidnapping, two counts of assault, and misdemeanor harassment for contacting the victim with a bodily fluid. However, prosecutors dropped the kidnapping charge after concluding that they would not be able to meet their burden of proof at trial. The defendant subsequently pled guilty to the greater assault charge, which, given his otherwise clean criminal history, carried a sentence of zero to two years in jail. The state and the defendant eventually reached a plea deal calling for a two-year sentence with one year suspended, and three years probation. The defendant also would receive credit for time served while wearing an ankle monitor. Significantly, this meant that he would face no additional jail time.

At the plea hearing, Judge Corey probed the prosecution about the adequacy of the proposed plea deal. 30 Of particular concern was that the crime was plainly sexual in nature, yet the defendant had not been charged with sexual assault and was not even required to register as a sex offender. The prosecutor explained that the defendant's actions, while appalling, did not qualify as a sex crime under Alaska law. The prosecutor also noted that the state had insisted on probation as a way to require the defendant to undergo sex-offender treatment. ${ }^{31}$

Judge Corey described the case as "breathtaking," 32 and commented that the proposed sentence "at first blush would really quite frankly strike me as way too light." 33 Nevertheless, he felt constrained by several aspects of Alaska law in determining whether to accept the agreement. Among other things, he could not consider the charges that had been dropped by the prosecution, nor could he propose a sentence aggravator on his own. ${ }^{34}$ After a 30-minute hearing, Judge Corey accepted the plea agreement, based heavily on the defendant's prospects for rehabilitation, as well as the judge's stated belief that the attorneys in the case knew "far better and more about the case than I do presently. They know more about what can be proven and what can't." 35

The decision to accept the plea deal made national news almost immediately, and quickly gave rise to a local movement calling itself No More Free Passes. The movement was animated by two central concerns: the perceived unjustness of the sentence, and the failure of Judge Corey to discuss the victim during the plea hearing. No More Free Passes accordingly identified two corresponding goals: to change the existing law, and to remove the judge who had approved the plea.

From the start, the approach taken by No More Free Passes differed significantly from the handful of previous successful anti-retention efforts with respect to source, platform, tone, and underlying assumptions about the proper role of the judiciary. Indeed, its tone and tactics most closely mirrored the Persky recall campaign months before. Three characteristics of the campaigns were particularly notable.

First, the push to remove the judge was organized and fortified primarily by those on the left side of the political spectrum, drawing their energy from the \#MeToo movement and the contemporaneous and controversial confirmation hearings for Supreme Court nominee Brett Kavanaugh. ${ }^{36}$ This was new. Historically, aggressive anti-retention campaigns have been initiated by conservative groups opposed to judicial decisions concerning capital punishment, abortion, same-sex marriage, and the state's taxing power. This development suggests that retention elections may now become an instrument for mobilization by partisans on both sides of the political spectrum.

Second, social media played a key role in spreading the antiretention message. No More Free Passes created a Facebook page just three days after Judge Corey approved the plea deal, and immediately began advocating for the judge's ouster. By November, the page had approximately 4,000 followers, and No More Free Passes was updating the page at least daily, eliciting thousands of viewer reactions in the process. No More Free Passes also created a GoFundMe page to solicit donations, and an Instagram page to spread its message. One of the group's founders, Elizabeth Williams, also promoted the cause on her personal Instagram page with hashtags like \#nomorefreepasses and \#nooncorey. And while No More Free Passes did not take to Twitter directly, the campaign benefited from dozens of sympathetic tweets by other users in the weeks leading up the election. To be sure, the anti-Corey campaign also used traditional media effectively, granting interviews and writing op-eds for local newspapers and broadcasters. But social media played a central role in getting the message out.

Finally, the anti-Corey campaign broke most significantly from previous anti-retention efforts in the way it presented the
30. See Daniella Rivera, No Jail Time for Man Who Pleaded Guilty in Strangling Assault (Sep. 19, 2018), available at https://www.ktva.com/story/39123509/anchorage-man-pleadsguilty-in-choking-sexual-assault-case.

31. See State of Alaska Department of Law, Press Release, Justin Schneider Sentenced in Accordance with Current Law (Sep. 21, 2018).

32. See Rivera, supra note 30.

33. See Michelle Theriault Boots, "One Free Pass": The Story Behind the
No-Jail Plea Deal that Drew Outrage from Alaskans, ANCHORAGE Daily News, Oct. 8, 2018.

34. See id.

35. Id.

36. See Daniella Rivera, Alaskans Rally Against Judge's Retention After Schneider Plea Deal (Oct. 6, 2018), available at https://www.ktva.com/story/39244261/alaskans-rally-againstjudges-retention-after-schneider-plea-deal. 
role of the judge. Previously, anti-retention campaigns had sought to convince voters that the targeted judges had acted unprofessionally by venturing beyond the limits of their authority. The fundamental message of the anti-Corey campaign, however, was that the judge had not done enough with his authority in the face of a potentially unjust outcome. In an op-ed published the week before the election, the founders of No More Free Passes wrote, "Judges hold one of the most powerful positions in modern society because we expect them to exercise judicial discretion." 37 This message represented a complete reversal from the themes of earlier anti-retention campaigns, which accused targeted judges of insufficient humility in exercising their judicial roles.

The anti-Corey campaign was also able to neutralize the issue of professional competence which typically influences retention voting. Just weeks before accepting the plea deal, Judge Corey had been unanimously recommended for retention by the Alaska Judicial Council on the basis of his strong performance evaluation. A good performance review helps to place isolated controversial decisions in context, and historically voters have been unwilling to remove a good judge based on a single case. Despite public reminders about his performance evaluation and op-eds from members of the bar urging voters to place the single decision in broader context, this time voters were unmoved. It represented the first time in Alaska's history that a judge was not retained after receiving a positive evaluation and recommendation.

In light of the unusual tenor and tactics of the campaign, there is good reason to view Judge Corey's non-retention as an anomaly. Indeed, every other attempt to target judges for specific decisions (as opposed to poor job performance) during the 2018 election cycle was unsuccessful. Consistent with the history of retention elections, these anti-retention campaigns only spoke to a limited portion of the voting population, and (where available) judicial performance evaluations seemed to serve as a bulwark against knee-jerk decisions to remove judges. The fact that the anti-Corey campaign bucked these trends is therefore noteworthy. Moreover, the particular facts of the case underlying Judge Corey's decision were broadly similar to the facts underlying Judge Persky's decision, the campaign strategies closely mirrored those of the anti-Persky campaign, and the proponents of the Persky recall offered enthusiastic public support to the antiCorey campaign. Given these facts, the non-retention of Judge Corey is probably best understood as part of a larger popular backlash situated in a specific cultural moment. ${ }^{38}$
At the same time, there is reason to see the anti-Corey campaign as something more than an isolated event, and to believe that the messaging and mobilization tactics borrowed from judicial recalls will become more prominent in future retention elections. Another anti-retention campaign from the fall of 2018-this time to unseat California Supreme Court Justice Carol Corriganillustrates the concern. Justice Corrigan was appointed to the court in 2005 and retained in 2006, entitling her to a subsequent twelve-year term. During that time, Justice Corrigan authored hundreds of opinions on a wide variety of issues, and was generally well-regarded as a jurist. As the 2018 election neared, prominent newspapers endorsed her retention. But activists launched a powerful campaign to remove her, based entirely on an opinion she had written ten years earlier.

In May 2008, Justice Corrigan dissented in part from California's landmark opinion legalizing same-sex marriage. In the dissent, she explained that she personally supported same-sex marriage rights, but believed that the issue was one for the voters, not the courts, to decide. ${ }^{39}$ After the state's voters reenacted the state's ban on same-sex marriage through Proposition 8 in November 2008, she (along with five other justices) upheld the election result.

Proposition 8 was eventually struck down in federal court, 40 but Justice Corrigan's dissent in the original same-sex marriage case was not forgotten. Like the campaign against Judge Corey, the campaign against Justice Corrigan eschewed charges of unprofessionalism or institutional overreach, focusing instead on the single substantive message that the justice had "voted twice against marriage equality." An anonymously authored Facebook page titled "Vote NO on Carol Corrigan-CA Supreme Court Justice Against Equality" posted at least eighteen sharable photos and videos urging Californians to vote against retention. On Twitter, the anti-Corrigan campaign was bolstered by tweets from prominent celebrities as well as ordinary citizens. ${ }^{41}$ Many social media posts had both a multiplier and a boomerang effect, originating in California before being picked up by friends and sympathizers around the country
37. Elizabeth Williams \& Isaac Williams, No More Free Passes: Don't Retain Judge Corey, Anchorage Daily News, Oct. 26, 2018 (emphasis added).

38. The emergent awareness of sexual harassment and sexual assault in North American culture in 2018 has led to heightened scrutiny of judicial sentencing practices for sex crimes in a number of courts. See, e.g., Protestors Want Judge Fired After "Disgraceful" Sentence Given to Sexual Assault Perpetrator (Nov. 10, 2018), available at https://bc.ctvnews.ca/protesters-want-judge-fired-after-disgraceful-sentence-given-to-sexual-assault-perpetrator-1.4172091; Thousands Sign Petition Calling for Judge in Shocking Oklahoma Child Rape Case to be Removed (Feb. 5, 2018), available at https://kfor.com/2018/02/05/thousands-sign-petition-calling-forjudge-in-shocking-oklahoma-child-rape-case-to-be-removed/.

39. See In re Marriage Cases, 183 P.3d 384, 468 (Cal. 2008) (Opinion of Corrigan, J.).

40. See Perry v. Schwartzenegger, 704 F. Supp.2d 921 (2010).

41. Olympic diver Greg Louganis, and actors Kal Penn and Willie Garson, among others, used their personal Twitter accounts to advocate against the retention of Justice Corrigan. Louganis's antiretention tweet generated attention from the mainstream media. See Rick Hurd, Diving Legend Greg Louganis Wants California Justice's Confirmation Bid to Belly Flop, SAn Jose Mercury News, Oct. 11, 2018. 
(and the world), who in turn urged their associates back in the justice's home state to cast a vote against her. As with Judge Corey, an essentially local election took on national (and international) dimensions.

In the end, the campaign against Justice Corrigan was unsuccessful, and she was retained for another term. But the ten-year gestation period of the anti-Corrigan campaign suggests that in at least some circumstances, anti-retention activists are willing to take the long view. In addition, the shared tactics of the anti-Corey, anti-Corrigan, and anti-Persky campaigns suggests that in at least some instances, the passions and substantive messages that more typically animate judicial recall elections can bleed into regularly scheduled retention elections.

For supporters of a professional and depoliticized judiciary, the introduction into retention elections of tactics and themes normally reserved for recall elections is a deeply disconcerting development. Recall elections are a powerful form of popular accountability, meant to be used only in the most egregious circumstances, and are by design difficult to initiate. Retention elections, by contrast, are designed with a different purpose in mind, and do not feature these important procedural safeguards. Judges appear automatically on the retention ballot, allowing a last-minute campaign against them to arise with no warning. As the anti-Corey campaign demonstrates, a passionate electorate can transform a standard retention bid into a de facto recall election in a matter of weeks.

Recall and retention can coexist, as long as each mechanism stays true to its intended purpose. But retention elections should not transform into regularly-scheduled recall elections by default. Using regular checks of professional accountability as an opportunity to impose outcome-based accountability would threaten the decisional independence of individual judges, and dramatically undermine the judiciary's overall legitimacy and institutional competence.

\section{"MOVING FORWARD"}

The day after Judge Corey lost his retention bid, the leader of No More Free Passes posted the following message on the group's Facebook page: "Moving forward, we will no longer be discussing Mr. Corey. I believe his family and friends when they tell me he is a great man, husband, and father. He deserves privacy and peace during this time. We wish him nothing but the best in his future." That sentiment may be cold comfort for the judge. It should be a wake-up call for all who continue to desire a judiciary that is professional, fair, and independent.

One must proceed cautiously in attempting to draw broad conclusions from limited data points. But the events of 2018 do suggest the ongoing need to focus voters on the importance of a professional and institutionally legitimate judiciary. This means emphasizing that judges must be accountable to their professional and institutional obligations, as well as the limits on judicial discretion that those obligations impose. More specifically, citizens should be reminded that judges are not at liberty simply to change or ignore laws with which they disagree. Rather, consistent with their authority and professional responsibilities, they must do their best to apply valid laws to the cases before them.

This is not to suggest that voters will-or even shouldtake a neutral view on the outcomes of specific cases. The decisions that animated the campaigns against Judge Persky, Judge Corey, and Justice Corrigan were quite fairly the subject of public debate and private anguish. But those campaigns also arose out of a mistaken belief that judges have the unfettered authority simply to do "the right thing," as opposed to laboring within their constitutional and institutional limitations. Members of the public should understand that the quality of the judiciary must be determined not by reference to a specific case, but rather by asking whether judges reach their decisions in a fair, accurate, and trustworthy manner.

Emphasizing judicial professionalism has a long and successful track record of helping to depoliticize judicial selection, but the message must be updated for the 2020s and beyond. In the twentieth century, judicial professionalism was equated with expertise, and the special training and skill that the legal profession required. The message worked because of the traditionally high regard given to experts in a given field. But the current era has seen an increase in public skepticism over expertise, with many Americans regarding "experts" as nothing more than an undifferentiated mass of wealthy elites. ${ }^{42}$ Consequently, it may no longer be enough to say that a judge should be retained because of her training, experience, and knowledge; it is also necessary to stress the judiciary's commitment to more modern notions of professionalism, such as transparency and continuous improvement. Courts themselves can take a role in this messaging, by routinely sharing the concrete steps they are taking to meet the needs of their users and the general public.

Courts can also be proactive about reaching out to other organizations to help spread the message of judicial professionalism. The organized bar has long been a loyal advocate for the judiciary, based on its intimate knowledge of the courts and respect for the rule of law. It is a logical place to start. But lawyers today are facing the same anti-elite backlash as judges. Courts may also need to develop connections with less traditional allies-including perhaps state legislators or community organizations - to reiterate the importance of judicial professionalism and institutional legitimacy. An ounce of prevention today will be worth it, lest the substantive moral certainty of recall elections become the prevailing lens through which all future judicial decisions are assessed.

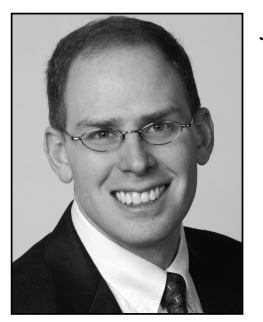

Jordan M. Singer is a Professor of Law at New England Law | Boston, where he teaches courses on civil litigation, judicial process, and intellectual property. His blog, The Interdependent Third Branch (www.interdependentcourts.com), tracks developments in court organization, administration, structure, and strategy, with an emphasis on how courts interact with their external environments. 